\title{
Two new species of the genus Anchonus Schoenherr, 1825 (Coleoptera: Curculionidae: Molytinae) in Dominican amber
}

\author{
George Poinar, Jr. and Andrei A. Legalov
}

\begin{abstract}
Two new species of the genus Anchonus Schoenherr, 1825, from the subfamily Molytinae, tribe Anchonini, are described from Dominican amber (Lower Miocene, 2015 million years old). Anchonus acrolepidotus sp. nov. is similar to Anchonus suillus (Fabricius, 1792) but differs in having its body covered with curved scales, rostrum separated from the head by a weak furrow, and a smaller body size. Anchonus bothynus sp. nov. is very similar to Anchonus acrolepidotus sp. nov. but differs in having the elytral intervals convex, pronotum densely punctate, wider elytra, a visible suture between the first and second ventrites, and larger body size. These specimens represent the first fossil records of the genus Anchonus.
\end{abstract}

George Poinar, Jr. Department of Integrative Biology, Oregon State University, Corvallis, Oregon 97331, USA. poinarg@science.oregonstate.edu

Andrei A. Legalov. Laboratory of Phylogeny and Faunogenesis, Institute of Systematics and Ecology of Animals, Siberian Branch, Russian Academy of Sciences, Frunze street, 11, Novosibirsk 630091, Russia; Altai State University, Lenina street, 61, Barnaul 656049, Russia. fossilweevils@gmail.com

Keywords: Curculionoidea; Molytinae; Anchonini; Tertiary weevils; new species

Submission: 27 April 2018. Acceptance: 20 August 2019.

\section{INTRODUCTION}

The oldest representative of the Curculionidae occurs in the Cretaceous (Aptian) of Mongolia (Legalov, 2014) and the earliest member of the Molytinae appears in the early Paleocene of the Russian Far East (Legalov, 2010). Molytine weevils become diverse in the Eocene (Scudder, 1876, 1893; Wickham, 1912, 1913; Cockerell, 1921; Hustache, 1942; Ulke, 1947; Haupt, 1950; Voss, 1953, 1972; Britton, 1960; Zherikhin, 1971; Legalov, 2010, 2015, 2016, 2018b), where more than 30 species from seven tribes are known. Only the fos-

http://zoobank.org/02977D67-C1B3-4621-87B6-64D05C9AC438

Poinar, Jr., George and Legalov, Andrei A. 2019. Two new species of the genus Anchonus Schoenherr, 1825 (Coleoptera: Curculionidae: Molytinae) in Dominican amber. Palaeontologia Electronica 22.3.59 1-10. https://doi.org/10.26879/882 palaeo-electronica.org/content/2019/2717-new-anchonus-in-dominican-amber

Copyright: October 2019 Paleontological Society.

This is an open access article distributed under the terms of Attribution-NonCommercial-ShareAlike 4.0 International (CC BY-NC-SA 4.0), which permits users to copy and redistribute the material in any medium or format, provided it is not used for commercial purposes and the original author and source are credited, with indications if any changes are made. creativecommons.org/licenses/by-nc-sa/4.0/ 
sil genus Velatis Poinar et Voisin, 2003, from the tribe Anchonini was described from Miocene Dominican amber (Poinar and Voisin, 2003).

The present study describes two fossil species in the genus Anchonus Schoenherr, 1825, from Dominican amber, thus expanding our knowledge of the Neotropical fauna of the Anchonini.

\section{MATERIAL AND METHODS}

The specimens were obtained from mines in the Cordillera Septentrional of the Dominican Republic. Dating of Dominican amber is still controversial, with the latest purposed age of $20 \mathrm{Ma}-15$ Ma based on foraminifera (Iturralde-Vinent and MacPhee, 1996) and the earliest as $45 \mathrm{Ma}-30 \mathrm{Ma}$ based on coccoliths (Schlee, 1990). In addition, Dominican amber is secondarily deposited in sedimentary rocks, which makes a definite age determination difficult (Poinar and Mastalerz, 2000). A range of ages for Dominican amber is possible as the amber is associated with turbiditic sandstones of the Upper Eocene to Lower Miocene Mamey Group (Draper et al., 1994). Dominican amber was produced by the leguminous tree, Hymenaea protera Poinar, 1991, and a reconstruction of the Dominican amber forest based on amber fossils indicated that the environment was similar to that of a present-day tropical moist forest (Poinar and Poinar, 1999).

The morphological terminology used in this paper follows Lawrence et al. (2010). We used terms "mucro" and "uncus" from Morimoto (1962) and consider mucro and premucro (secondary mucro sensu Kuschel (1951)) as one structure (Legalov, 2018a).

Observations and photographs were made with a Nikon SMZ-10 stereoscopic microscope (Tokyo, Japan) and Zeiss Stemi 2000-C binocular microscope (Jena, Germany). Helicon Focus Pro X64 (New York, NY) was used to stack photos for better clarity and depth of field.

\section{SYSTEMATIC PALAEONTOLOGY}

Subfamily MOLYTINAE Schoenherr, 1823

Tribe ANCHONINI Imhoff, 1856

Genus ANCHONUS Schoenherr, 1825

Anchonus acrolepidotus sp. nov.

Figures 1-5

zoobank.org/1E9A8C33-DD0C-487E-ACD4-7D80E776AE1A

Holotype. Deposited in Poinar amber collection maintained at Oregon State University, Corvallis (USA: Oregon) (accession \# D-C-16A).

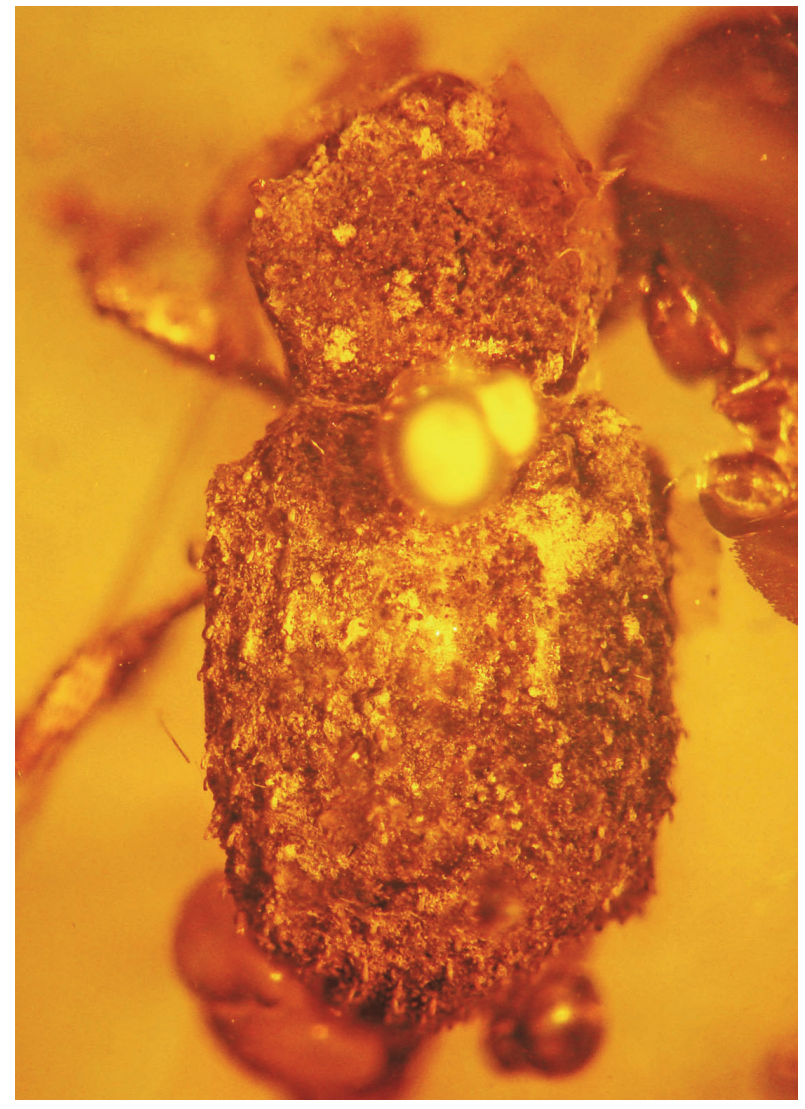

FIGURE 1. Dorsal view of Anchonus acrolepidotus sp. nov. in Dominican amber. Bar equals $0.7 \mathrm{~mm}$.

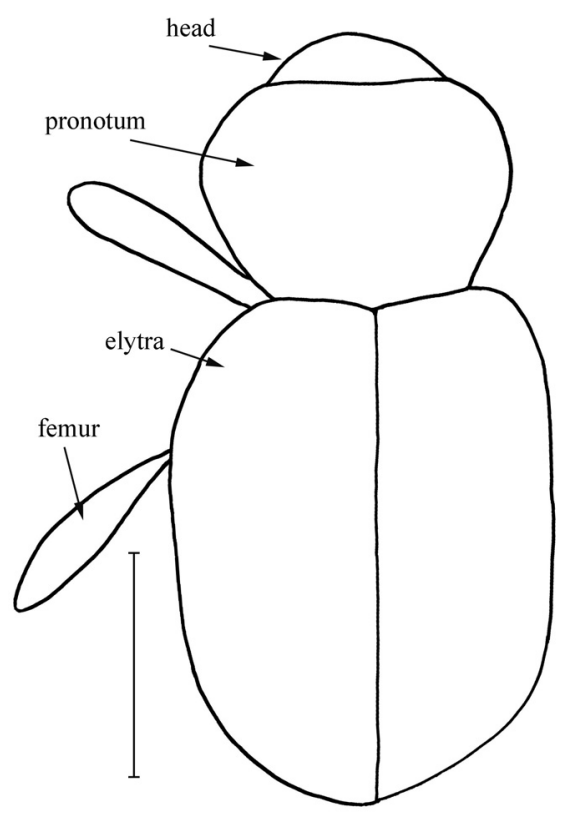

FIGURE 2. Drawing of dorsal view of Anchonus acrolepidotus sp. nov. in Dominican amber. Bar equals 1.0 $\mathrm{mm}$. 


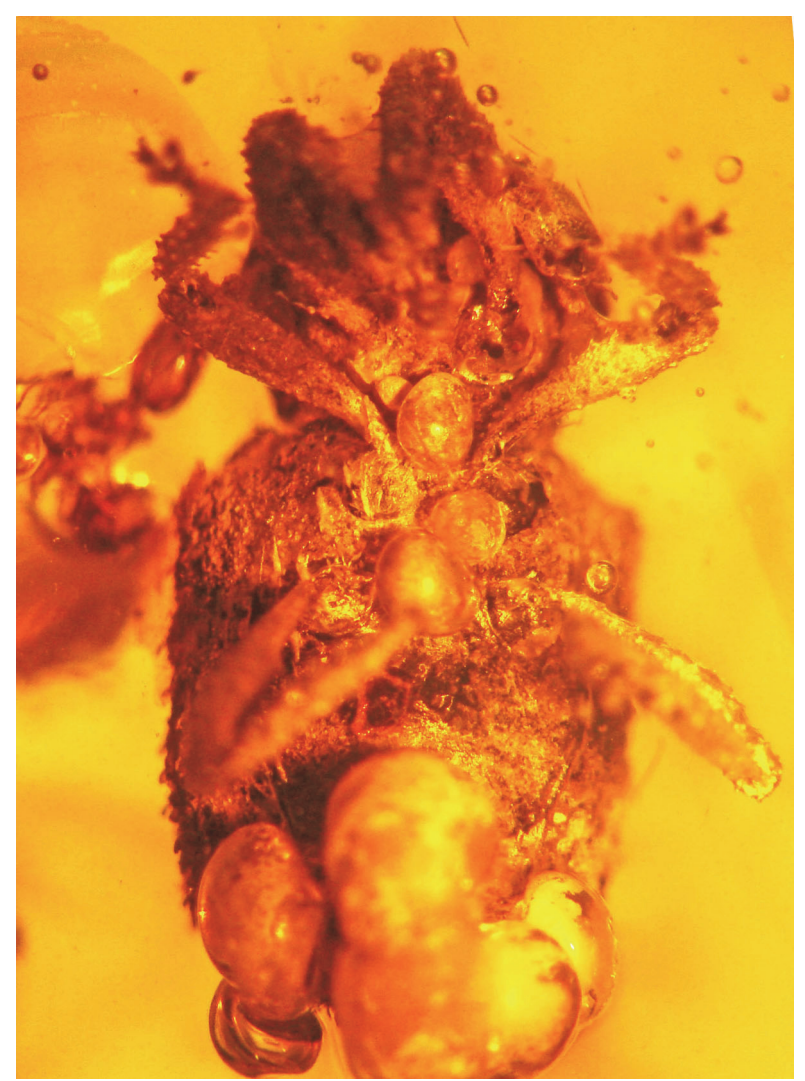

FIGURE 3. Ventral view of Anchonus acrolepidotus sp. nov. in Dominican amber. Bar equals $0.7 \mathrm{~mm}$.
Description. The specimen is complete, however, some air bubbles are adhering to its body. Body length (without rostrum), $3.5 \mathrm{~mm}$; rostrum length, $0.7 \mathrm{~mm}$. Body dark brown to black. Antennae and legs brown. Body convex dorsally, with curved scales extended to apex.

Head capsule not constricted behind eyes. Mandibles small. Rostrum elongate, 3.4 times as long as wide at apex, 3.0 times as long as wide in middle and at base, weakly curved, densely punctate, lacking carinae, separated from head by furrow. Antennal scrobes visible from above anteriorly, directed under but not reaching eyes. Antennae long, thin, geniculate, inserted in apical third of rostrum. Antennomeres subconical; first antennomere not reaching eyes, 9.0 times as long as wide; second antennomere 2.5 times as long as wide, 0.2 times as long as and 0.7 times as narrow as first antennomere; third antennomere subequal to second antennomere; fourth to eighth antennomeres subequal in width; fourth antennomere 2.5 times as long as wide, 0.5 times as long as third antennomere; fifth antennomere subequal to third antennomere; sixth antennomere 1.1 times as long as wide; sixth to eighth antennomeres subequal in length; club compact, 3.0 times as long as wide; ninth antennomere 0.9 times as long as wide, 1.4 times as long as and 1.7 times as wide as eighth antennomere; suture between tenth and eleventh antennomeres absent. Eyes oval, not protruding

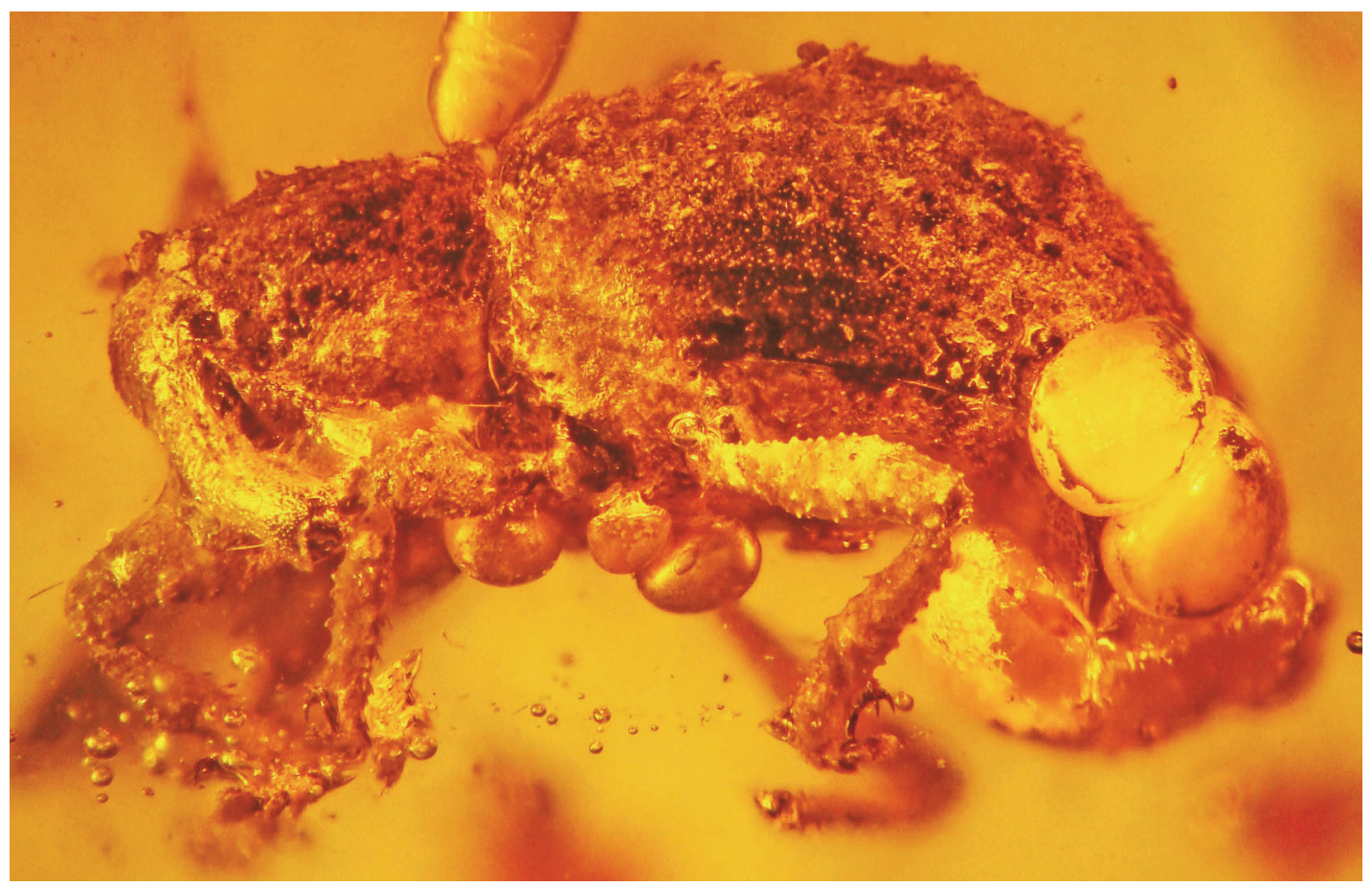

FIGURE 4. Lateral view of Anchonus acrolepidotus sp. nov. in Dominican amber. Bar equals $0.7 \mathrm{~mm}$. 


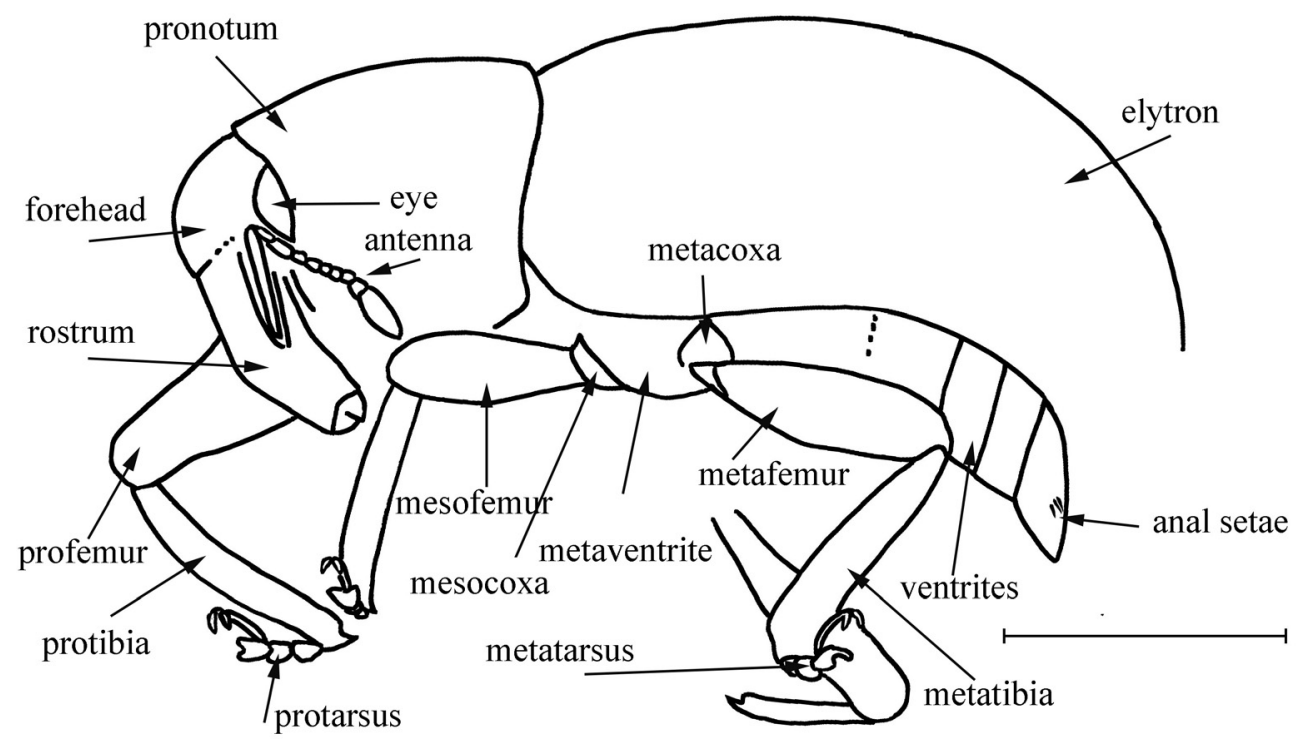

FIGURE 5. Drawing of lateral view of Anchonus acrolepidotus sp. nov. in Dominican amber. Bar equals $1.0 \mathrm{~mm}$.

from head, placed low down. Temples short. Forehead quite wide, narrower than rostrum base width, flattened.

Pronotum with arcuate sides, 1.5 times as long as length of rostrum, 1.3 times as long as wide at apex, 0.9 times as long as wide in middle, and 1.2 times as long as wide at base; disc flattened, rarely and coarsely punctate, without tubercles. Greatest width before middle. Scutellum absent.

Elytra quite wide, 1.9 times as long as pronotum, 1.6 times as long as wide at base, 1.6 times as long as wide in middle, 2.2 times as long as wide in apical fourth; with smoothed humeri, all intervals similar, flat, narrow, 0.9-1.0 times as long as width of striae, smooth; punctate striae with punctures distinct, regular, as long as or larger than intervals; ninth and tenth striae not merging at level of mesocoxae.

Prosternum not excavated, with postocular lobe. Precoxal portion of prosternum long, 1.5 times as long as precoxal cavity length. Procoxal cavities rounded, located before base of prosternum, connected. Postcoxal portion of prosternum 0.5 times as long as length of precoxal cavity. Mesocoxal cavities rounded and separated. Metaventrite convex and short, 0.9 times as long as metacoxal cavity. Metanepisterna absent. Abdomen flattened; first to fifth ventrites oriented in one plane; first and second ventrites elongate and fused, suture between them not visible, first ventrite about 2.1 times as long as metacoxal cavity; second ventrite subequal in length to first ventrite; third ventrite about 0.3 times as long as second ventrite; fourth ventrite equal in length to third ventrite; fifth ventrite 2.6 times as long as fourth ventrite, with anal setae.

Legs long. Metacoxae almost subglobular, reaching margin of elytra. Trochanters not separating femora and coxae. Femora thickened and punctate, without teeth; profemur 4.4 times as long as wide; metafemur 4.8 times as long as wide. Tibiae almost straight, with apical comb of setae, with uncus and two distinct groups of setae, small mucro; uncus larger than claws; protibiae 6.6 times as long as wide in middle; metatibiae 8.6 times as long as wide in middle. Tarsi quite long, pseudotetramerous; first and second tarsomeres trapezoidal; third tarsomere bilobed; fifth tarsomere long. Protarsi: first tarsomere 2.9 times as long as wide; second tarsomere 1.7 times as long as wide, 0.7 times as long as and subequal in width to first tarsomere; third tarsomere 1.1 times as long as wide, 1.1 times as long as and 1.7 times as wide as second tarsomere; fifth tarsomere 4.0 times as long as wide, 1.5 times as long as and 0.4 times as narrow as third tarsomere; mesotarsi: first tarsomere 1.7 times as long as wide; second tarsomere 1.3 times as long as wide, 0.8 times as long as and subequal in width to first tarsomere; third tarsomere equal in length and width, 1.5 times as long as and 2.0 times as wide as second tarsomere; fifth tarsomere 3.0 times as long as wide, 1.5 times as long as and 0.5 times as narrow as third tarsomere; metatarsi: first tarsomere 1.5 times as long as wide; second tarsomere 1.3 times as wide as long, 0.8 times as long as and subequal in width to first tarsomere; 
third tarsomere equal in length and width, 1.2 times as long as and 1.3 times as wide as second tarsomere; fifth tarsomere 3.7 times as long as wide, 1.8 times as long as and 0.5 times as narrow as third tarsomere. Claws free, without teeth.

Type Locality. Amber mine in the northern portion of the Dominican Republic.

Etymology. The species epithet is based on the Greek "akron" = tip and the Greek "lepidotos" = scaly, in reference to the curved scales that extend to the apex of the body.

Remarks. The new species is similar to Anchonus suillus (Fabricius, 1792) from Hispaniola, Guadeloupe, and Puerto Rico, but differs in having its body with curved scales extending to the apex, rostrum separated from the head by a weak furrow, thicker and larger tarsal claws, and a smaller body size.

\section{Anchonus bothynus sp. nov.} Figures 6-9

\section{zoobank.org/993962DA-1839-412B-8354-264ECD97B4C8}

Holotype. Deposited in the American Museum of Natural History (USA, New York) (AMNH no. DR-8396).

Description. The specimen is complete. Body length (without rostrum), $5.9 \mathrm{~mm}$; rostrum length, $1.3 \mathrm{~mm}$. Body black, convex dorsally, with curved scales extending to apex.

Head capsule not constricted behind eyes. Mandibles small. Rostrum elongate, 3.7 times as long as wide in middle and at base, curved, punctate, lacking carinae, separated from head by furrow. Antennal scrobes visible from above anteriorly, directed under but not reaching eyes. Antennae long, thin, geniculate, inserted in apical third of rostrum. Antennomeres subconical; first antennomere not reaching eyes, 9.0 times as long as wide; second antennomere 2.5 times as long as wide, 0.2 times as long as and 0.7 times as narrow as first antennomere; third antennomere 2.1 times as long as wide, 0.8 times as long as second antennomere; fourth antennomere 1.8 times as long as wide; fifth antennomere 1.4 times as long as wide, 0.9 times as long as fourth antennomere; sixth antennomere 1.4 times as long as wide, 0.9 times as long as fifth antennomere; seventh antennomere 1.3 times as long as wide, 0.9 times as long as sixth antennomere; club compact. Eyes oval, not protruding from head. Forehead wide.

Pronotum with arcuate sides, 1.2 times as long as length of rostrum, 1.4 times as long as wide at apex, 0.8 times as long as wide in middle and 0.9 times as long as wide at base; disc flattened,

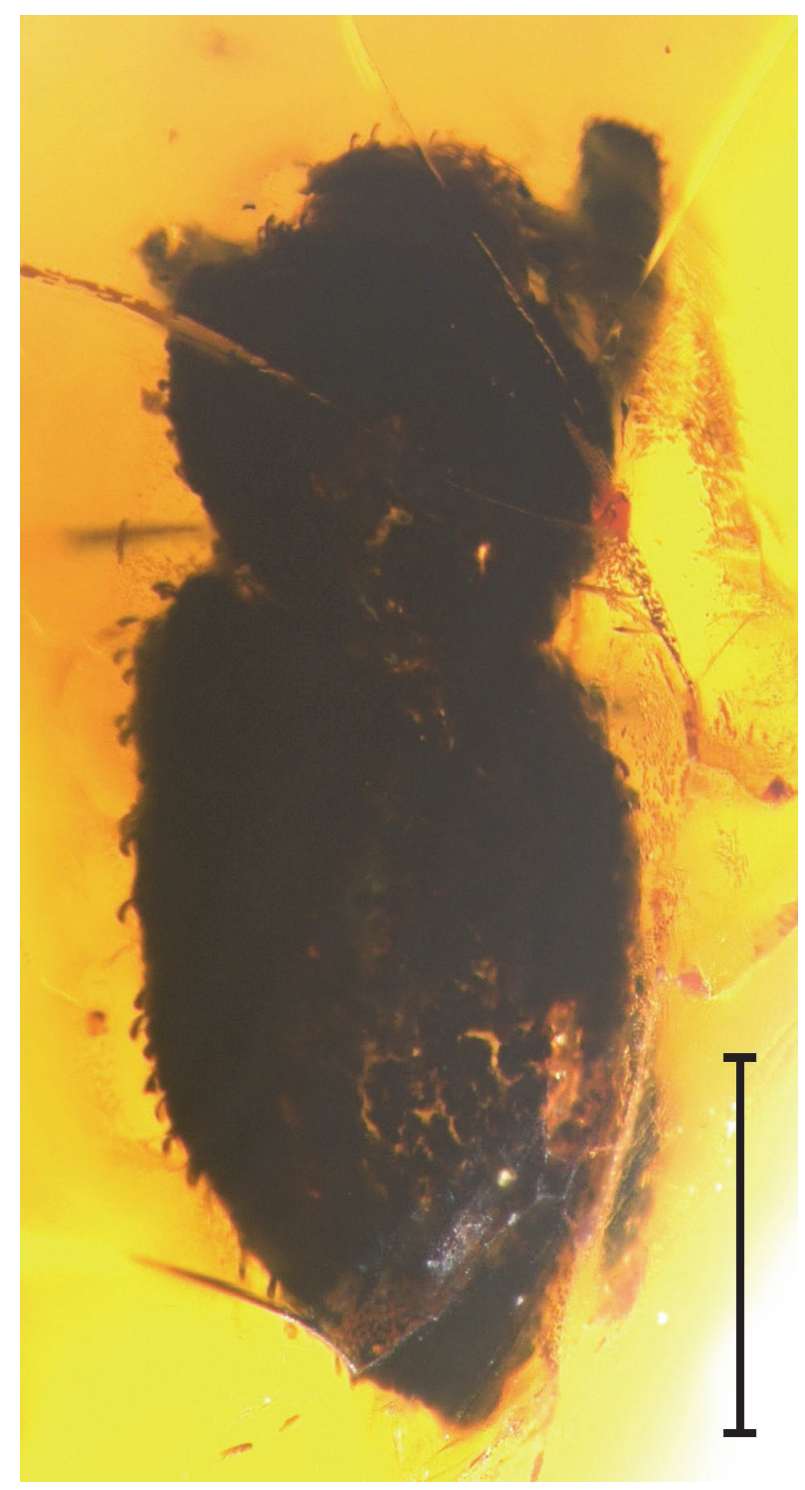

FIGURE 6. Dorsal view of Anchonus bothynus sp. nov. in Dominican amber. Bar equals $1.0 \mathrm{~mm}$.

densely and coarsely punctate, without tubercles. Widest before middle. Scutellum absent.

Elytra wide, 2.2 times as long as pronotum, 1.6 times as long as wide at base, 1.3 times as long as wide in middle, 1.9 times as long as wide in apical fourth; with smoothed humeri, all intervals similar, convex, narrower than striae; punctate striae regular; ninth and tenth striae not merging at level of mesocoxae.

Prosternum not excavated, with postocular lobe. Precoxal portion of prosternum long. Procoxal cavities rounded, located before base of prosternum, connected. Postcoxal portion of prosternum short. Mesocoxal cavities rounded and separated. Metaventrite short, 0.9 times as long as 


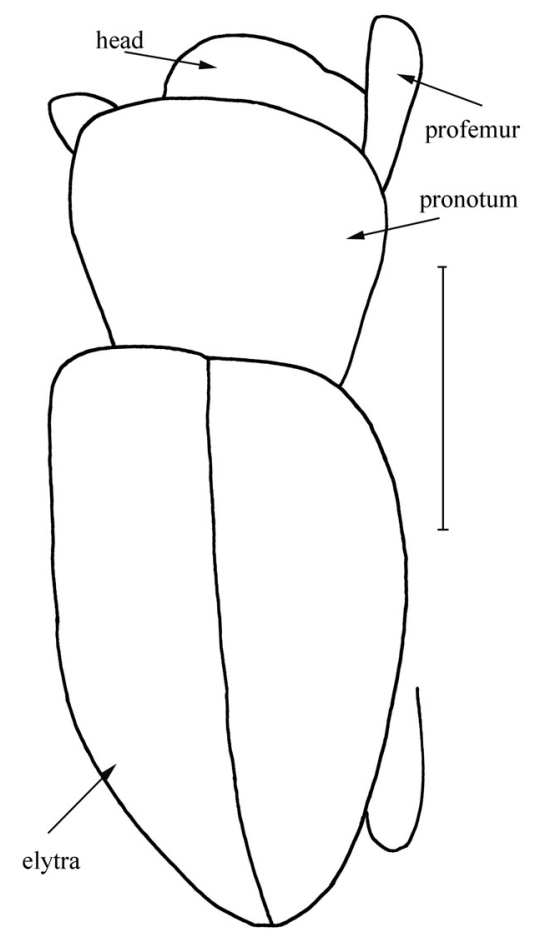

FIGURE 7. Drawing of dorsal view of Anchonus bothynus sp. nov. in Dominican amber. Bar equals $1.0 \mathrm{~mm}$. length of metacoxal cavity. Metanepisterna absent. Abdomen flattened; first to fifth ventrites oriented in one plane; first and second ventrites elongate and fused, suture between them visible, first ventrite 1.8 times as long as metacoxal cavity; second ventrite 0.7 times as long as first ventrite; third and fourth ventrites short.

Legs long. Metacoxae almost subglobular, reaching margin of elytra. Trochanters not separating femora and coxae. Femora thickened and punctate, without teeth; mesofemur about 4.5 times as long as wide; metafemur about 4.2 times as long as wide. Tibiae almost straight, with apical comb of setae, with uncus and two distinct groups of setae, small mucro; uncus larger than claws; protibiae 4.6 times as long as wide in middle; metatibiae 4.2 times as long as wide in middle. Tarsi quite long, pseudotetramerous; first and second tarsomeres trapezoidal; third tarsomere bilobed; fifth tarsomere long. Claws free, without teeth.

Type Locality. Amber mine in the northern portion of the Dominican Republic.

Etymology. The species epithet is taken from the Greek "bothynos" = pit, in reference to the densely punctate pronotum.

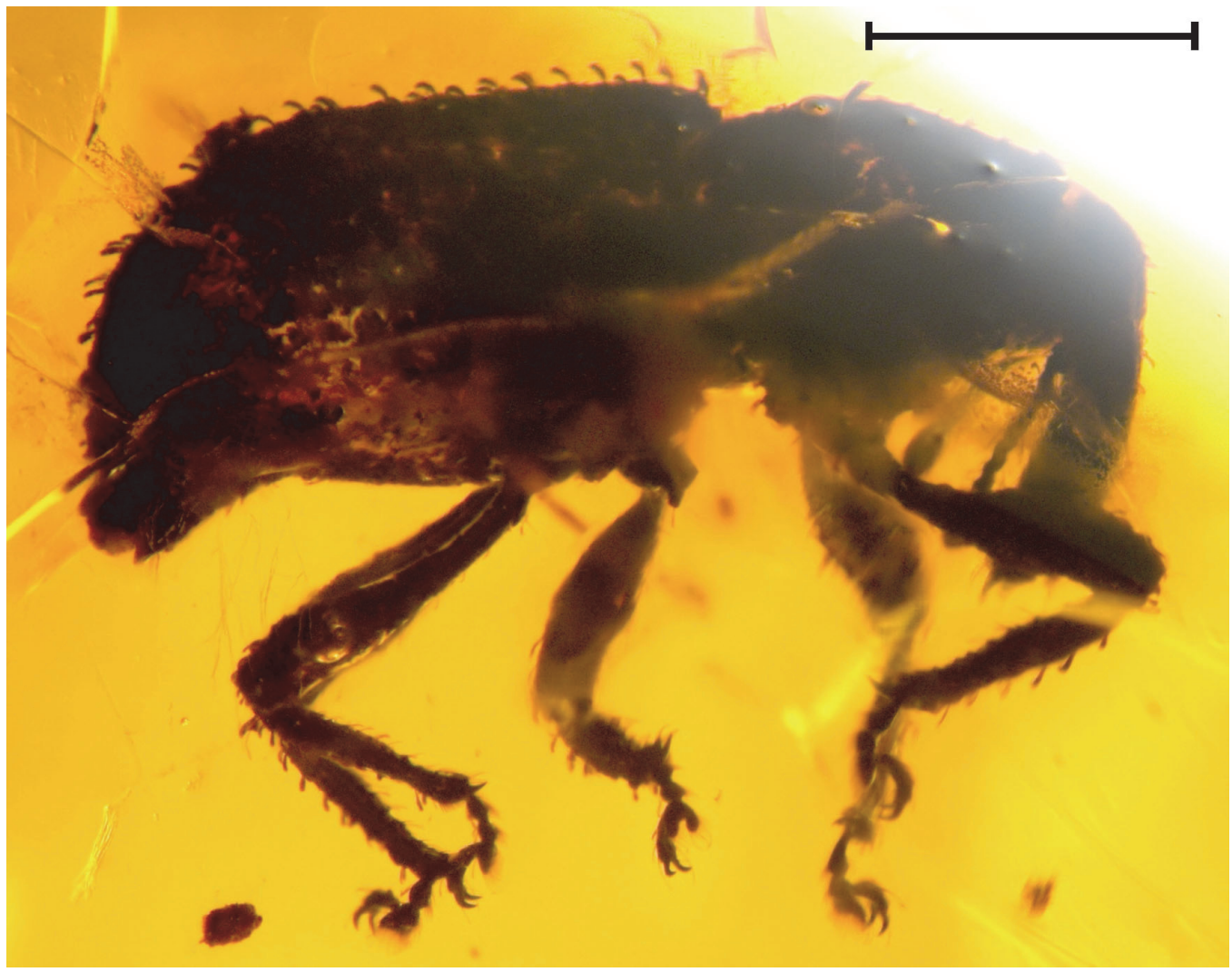

FIGURE 8. Lateral view of Anchonus bothynus sp. nov. in Dominican amber. Bar equals $1.0 \mathrm{~mm}$. 


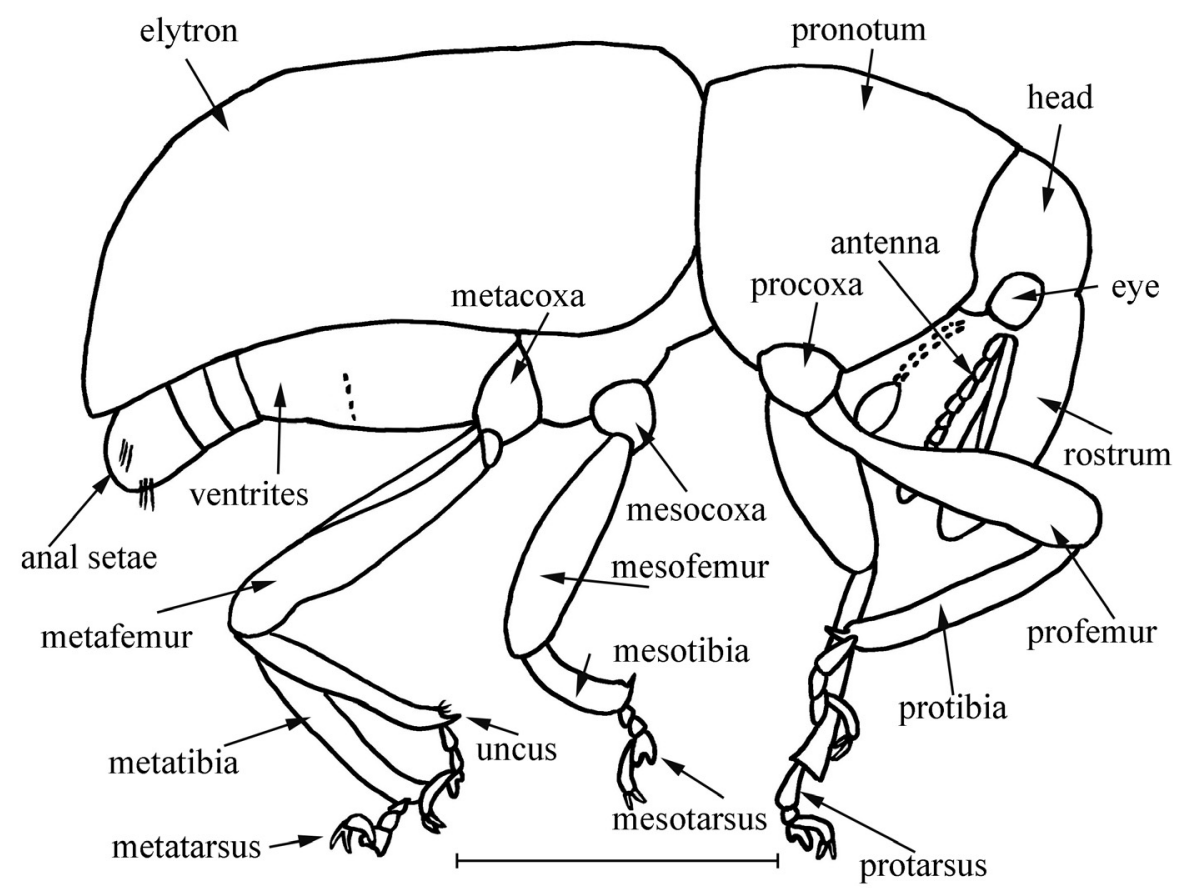

FIGURE 9. Drawing of lateral view of Anchonus bothynus sp. nov. in Dominican amber. Bar equals $1.0 \mathrm{~mm}$.

Remarks. The new species is very close to Anchonus acrolepidotus sp. nov. but differs by the elytral intervals convex, pronotum densely punctate, wider elytra, suture between first and second ventrites visible, wider tibiae, and larger body size.

\section{Key to species of the genus Anchonus from Hispaniola}

1. Rostrum separated from head by strong furrow. Body with subparallel scales. Tarsal claws thin and small. . . . . . . . . . . . . . Anchonus suillus

- Rostrum separated from head by weak furrow. Body with scales extending to the apex. Tarsal claws thick and large . . . . . . . . . . .

2. Elytral intervals flat. Pronotum rarely punctate. Elytra 1.6 times as long as wide in middle. Body size small $(3.5 \mathrm{~mm})$

. . . . . . . . Anchonus acrolepidotus sp. nov.

- Elytral intervals convex. Pronotum densely punctate. Elytra 1.3 times as long as wide in middle. Body size large $(5.9 \mathrm{~mm})$

. . . . . . . . . Anchonus bothynus sp. nov.

\section{DISCUSSION}

The specimens were placed in the family Curculionidae based on the elongate and fused first and second ventrites, the first to fifth ventrites oriented in one plane, geniculate antennae, and the tibiae with unci. They are assigned to the subfamily
Molytinae since the fifth ventrite has anal setae, the metacoxae reach the margin of the elytra, and the uncus is larger than the claws. The prosternum without excavation, the metacoxae almost subglobular, and rostrum separated from the head by a furrow are diagnostic characters of the tribe Anchonini. The new species are placed in the genus Anchonus because the rostrum lacks carinae, the pronotum lacks tubercles, all intervals are similar, and the striae have distinct, regular punctures as long as or longer than the intervals.

The tribe Anchonini is richly represented in the New World, and only a few of its representatives live in other regions of the world (Lyal, 2014). The fauna of Central and South America is most diverse (Champion, 1902; Voisin, 1991, 1992b, 1992c, 1992d, 1994, 1995, 1996, 1997a, 1997b, $2000,2006,2010)$. Six genera with a small number of species are distributed on the islands of the West Indies (O'Brien and Wibmer, 1982; Voisin, 1992a, 1994). Only one extant Anchonus suillus lives on Hispaniola (Perez-Gelabert, 2008). Both described new fossil species resemble it. Possibly in the Miocene when Hispaniola was larger, it contained additional species of the genus Anchonus.

Present-day representatives of the tribe Anchonini are found in several environments. One of these is under the bark or on branches of decaying trees. Another is beneath driftwood or seaweed 
on beaches. Their small eyes and lack of inner wings indicate that they occur in cryptic habitats (Blatchley and Leng, 1916).

\section{ACKNOWLEDGEMENTS}

We are grateful to A. Yu. Solodovnikov (Denmark: Copenhagen) for providing the opportunity to study comparative material deposited in the Natural History Museum of Denmark (Copenhagen).

\section{REFERENCES}

Blatchley, W.S. and Leng, C.W. 1916. Rhynchophora or Weevils of North Eastern America. The Nature Publishing Company, Indianapolis. https://doi.org/10.5962/bhl.title.1557

Britton, E.B. 1960. Beetles from the London clay (Eocene) of Bognor regis, Sussex. Bulletin of the British Museum Natural History. Geology, 4:27-50.

Champion, G.C. 1902. Insecta. Coleoptera. Rhynchophora. Curculionidae. Curculioninae. Biologia Centrali-Americana, 4:1-144. https://doi.org/10.5962/bhl.title.9237

Cockerell, T.D.A. 1921. Some Eocene insects from Colorado and Wyoming. Proceedings of the United States National Museum, 49:283-303. https://doi.org/10.5479/si.00963801.592358.29

Draper, G., Mann, P., and Lewis, J.F. 1994. Hispaniola, p. 129-150. In Donovan, S. and Jackson, T.A. (eds.), Caribbean Geology: An Introduction. The University of the West Indies Publishers' Association, Kingston.

Fabricius, J. C. 1792. Entomologia Systematica Emendate et Aucta. Secundum Classes, Ordines, Genera, Species Adjectis Synonimis, Locis, Observationibus, Descriptionibus. Vol. 1. Proft, Hafniae. (in Latin). https://doi.org/10.5962/bhl.title.122153

Haupt, H. 1950. Die Käfer (Coleoptera) aus der Eozänen Braunkohle des Geiseltales. Geologica, 6:1-168. (In German)

Hustache, A. 1942. Un curculionide de l'ambre de la Baltique. Bulletin Mensuel de la Société Linnéenne de Lyon, 11:108-109. (In French). https://doi.org/10.3406/linly.1942.9675

Imhoff, L. 1856. Versuch einer Einfuhrung in das Studium der Koleopteren. Author, Basel. (In German)

Iturralde-Vinent, M.A. and MacPhee, R.D.E. 1996. Age and paleogeographic origin of Dominican amber. Science, 273:1850-1852. https://doi.org/10.1126/science.273.5283.1850

Kuschel, G. 1951. Revision de Lissorhoptrus LeConte y generos vecinos de America. Revista Chilena de Entomologia, 1:23-74.

Lawrence, J.F., Beutel, R.G., Leschen, R.A.B., and Slipinski, S.A. 2010. Chapter 2. Glossary of morphological terms, p. 9-20. In Leschen, R.A.B. and Beutel, R.G. (eds.), Handbook of Zoology. Arthropoda: Insecta. Tb. 40: Coleoptera (Beetles). Vol. 2: Morphology and Systematics (Elateroidea, Bostrichformia, Cucujiformia partim). De Gruyter, Berlin. https:// doi.org/10.1515/9783110911213.9

Legalov, A.A. 2010. Checklist of Mesozoic Curculionoidea (Coleoptera) with description of new taxa. Baltic Journal of Coleopterology, 10:71-101.

Legalov, A.A. 2014. The oldest Brentidae and Curculionidae (Coleoptera: Curculionoidea) from the Aptian of Bon-Tsagaan. Historical Biology, 26:6-15. https://doi.org/10.1080/ 08912963.2012.751103

Legalov, A.A. 2015. Fossil Mesozoic and Cenozoic weevils (Coleoptera, Obrienioidea, Curculionoidea). Paleontological Journal, 49:1442-1513. https://doi.org/10.1134/ S0031030115130067

Legalov, A.A. 2016. New weevils (Curculionidae) in Baltic amber. Paleontological Journal, 50:970-985. https://doi.org/10.1134/S0031030116090057

Legalov, A.A. 2018a. A new weevil, Burmorhinus georgei gen. et sp. nov. (Coleoptera; Curculionidae) from the Cretaceous Burmese amber. Cretaceous Research, 84:13-17. https://doi.org/10.1016/j.cretres.2017.11.002

Legalov, A.A. 2018b. New weevils (Coleoptera, Curculionoidea) from the Eocene of the Green River, United States: Part 1. Paleontological Journal, 52:294-302. https://doi.org/10.1134/ S0031030118030061 
Lyal, Ch.H.C. 2014. Molytinae Schoenherr, 1823, p. 529-569. In Leschen, R.A.B. and Beutel, R.G. (eds.), Handbook of Zoology. Arthropoda: Insecta. Tb. 40: Coleoptera (Beetles). Vol. 3: Morphology and Systematics (Phytophaga). De Gruyter, Berlin. Morimoto, K. 1962. Comparative morphology and phylogeny of the superfamily Curculionoidea of Japan (Comparative morphology, phylogeny and systematics of the superfamily Curculionoidea of Japan. I). Journal of the Faculty of Agriculture, Kyushu University, 11:331-373.

O'Brien, C.W. and Wibmer, C.J. 1982. Annotated checklist of the weevils (Curculionidae sensu latu) of North America, Central America and the West Indies (Coleoptera: Curculionoidea). Memoirs of the American Entomological Institute, 34:1-382.

Perez-Gelabert, D.E. 2008. Arthropods of Hispaniola (Dominican Republic and Haiti): a checklist and bibliography. Zootaxa, 1831:1-530. https://doi.org/10.11646/zootaxa.1831.1.1

Poinar, G.O., Jr. 1991. Hymenaea protera sp. n. (Leguminosae, Caesalpinioideae) from Dominican amber has African affinities. Experientia, 47:1075-1082. https://doi.org/10.1007/ bf01923347

Poinar, G.O., Jr. and Mastalerz, M. 2000. Taphonomy of fossilized resins: determining the biostratinomy of amber. Acta Geologica Hispanica, 35:171-182.

Poinar, G.O., Jr. and Poinar. R. 1999. The Amber Forest. Princeton University Press, Princeton.

Poinar, G.O., Jr. and Voisin, J.F. 2003. A Dominican amber weevil, Velatis dominicana gen. n., sp. n. and key to the genera of the Anchonini (Molytinae, Curculionidae), Nouvelle Revue d'Entomologie, 19:373-381.

Schlee, D. 1990. Das Bernstein-Kabinett. Begleitheft zur Bernsteinausstellung im Museum am Löwentor, Stuttgart, 28:1-100. (In German)

Schoenherr, C.J. 1823. Curculionides [Tabula synoptica familiae Curculionidum], Isis von Oken, 1823:1132-1146. (in Latin)

Schoenherr, C.J. 1825. Continuatio [Tabula synoptica familiae Curculionidum], Isis von Oken, 1825:581-588. (In Latin)

Scudder, S.H. 1876. Fossil Coleoptera from the Rocky Mountain Tertiaries. Bulletin of the United States Geological and Geographical Survey of the Territories, 2:77-87.

Scudder, S.H. 1893. Tertiary rhynchophorous Coleoptera of the United States. Monographs of the United States Geological Survey, 21:1-206. https://doi.org/10.5962/bhl.title.9006

Ulke, T. 1947. A new genus and species of Curculionidae (Coleoptera) in Baltic amber. Notulae Naturae, 19:1-5.

Voisin, J.F. 1991. Description du genre Mincies nov. et de M. espeletiae sp. n. des Paramos du Venezuela (Coleoptera, Curculionidae). Nouvelle Revue d'Entomologie, 8:67-70. (In French)

Voisin, J.F. 1992a. Sur le genre Ixanchonus nov. et sur la véritable identité de Anchonus pudens auct. (Col. Curculionidae Molytinae). Bulletin de la Société Enlomologique de France, 96:399-402. (In French)

Voisin, J.F. 1992b. Description du genre Baillytes nov. et des espèces B. tauzini nov. et B. moreti nov. d'Amérique du Sud (Coleoptera, Curculionidae). Nouvelle Revue d'Entomologie, 8:427432. (In French)

Voisin, J.F. 1992c. Gibbanchonus n. gen. et G. krausci n. sp. du Matto Grosso (Brésil) (Insecta, Coleoptera, Curculionidae: Molytinae). Reichenbachia, 29:93-95. (In French)

Voisin, J.F. 1992d. Notes sur les genres de la tribu des Anchonini. 1. Généralités, redéfinition du genre Anchonus Schönherr et description de cinq genres et de deux sous-genres nouveaux (Coleoptera, Curculionidae). Nouvelle Revue d'Entomologie, 9:259-271. (In French)

Voisin, J.F. 1994. Notes sur la tribu des Anchonini. 2. Description de quatre genres nouveux et revue de six anciens (Coleoptera, Curculionidae). Nouvelle Revue d'Entomologie, 10:327340. (In French)

Voisin, J.F. 1995. Description du genre Brevanchonus nov., et de deux espèces nouvelles du genre Baillytes Voisin, de l'Equateur (Coleoptera, Curculionidac). Nouvelle Revue d'Entomologie, 11:247-253. (In French)

Voisin, J.F. 1996. Description d'Acorep dentirostris sp. nov. et du sous-genre Dentiacorep nov. (Col. Curculionidae). Nouvelle Revue d'Entomologie, 12:303-304. (In French)

Voisin, J.F. 1997a. Description de Sefites valeriae n. gen., n. sp. (Coleoptera, Curculionidae). Bulletin de la Société entomologique de France, 102:39-41. (In French)

Voisin, J.F. 1997b. Description du genre Perraultes nov., et de l'espèce $P$. hebes nov., de Colombie (Coleoptera, Curculionidae). Nouvelle Revue d'Entomologie, 14:95-97. (In French) 
Voisin, J.F. 2000. Description d'un genre nouveau et de deux espèces nouvelles d'Anchonini de l'Equateur (Coleoptera, Curculionidae). Bulletin de la Société entomologique de France, 105:289-292. (In French)

Voisin, J.F. 2006. Description of genus Capsonotus nov. and Sulconotus nov., from Ecuador and Venezuela, with four new related species (Curculionidae, Molytinae). Nouvelle Revue d'Entomologie, 23:349-359. (In French)

Voisin, J.F. 2010: Mallanchonus, remarkable new genus of the tribe Anchonini, and description of M. lalisae n. sp. (Coleoptera, Curculionidae). Nouvelle revue d'entomologie, 26:23-26. (In French)

Voss, E. 1953. Ergänzende Ausführungen zur Gattung Promecops Schoenh. und Pseudeudius Voss an hand typischer Exemplare aus dem Riksmuseum Stockholm. Arkiv för Zoologi, 4:423-438. (In German)

Voss, E. 1972. Einige Rüsselkäfer der Tertiärzeit aus baltischen Bernstein (Coleoptera, Curculionoidea). Steenstupia, 2:167-181. (In German)

Wickham, H.F. 1912. On some fossil rhynchophorous Coleoptera from Florissant, Colorado. Bulletin of the American Museum of Natural History, 31:41-55.

Wickham, H.F. 1913. Fossil Coleoptera from the Wilson Ranch near Florissant, Colorado. Bulletin from the Laboratories of Natural History of the State University of lowa, 6:3-29.

Zherikhin, V.V. 1971. On weevils (Insecta, Coleoptera) from the Baltic amber. Trudy Paleontologicheskogo Instituta Akademii Nauk SSSR, 130:197-209. (In Russian) 